Uralic studies, languages, and researchers

Edited by Sándor Szeverényi 
Studia uralo-altaica 54

Redigunt:

Katalin Sipőcz

András Róna-Tas

István Zimonyi 
Uralic studies, languages, and researchers

Proceedings of the $5^{\text {th }}$ Mikola Conference 19-20, September 2019

Edited by Sándor Szeverényi

Szeged, 2021 
(C) University of Szeged,

Department of Altaic Studies,

Department of Finno-Ugrian Philology

All rights reserved. No part of this book may be reproduced, stored in a retrieval system, or transmitted in any form or by other means, electronic, mechanical, photocopying, recording or otherwise, without the prior permission in writing of the author or the publisher.

Printed in 2021.

Printed by: Innovariant Ltd., H-6750 Algyő, Ipartelep 4.

ISBN 978-963-306-803-8 (printed)

ISBN 978-963-306-804-5 (pdf)

ISSN 0133-4239 (Print)

ISSN 2677-1268 (Online) 
Table of contents

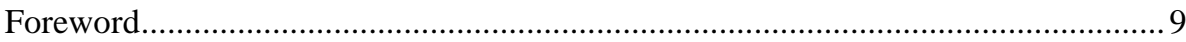

Sándor Szeverényi

Notes on Nicolaes Witsen and his Noord en Oost Tartarye. 11 Rogier Blokland

Undiscovered treasures: From the field research archive to the digital database......27 Beáta Wagner-Nagy, Chris Lasse Däbritz, and Timm Lehmberg

On the language use of the first Finnish medical text 45

Meri Juhos

Sajnovics, the responsible fieldworker 55

Sándor Szeverényi

The life and work of the Saami theologian and linguist: Anders Porsanger 71

Ivett Kelemen

The use and semantics of the Northern Mansi diminutive -riś $r \partial s$ ś 81

Bernadett Bíró

The event of "giving" and "getting" in Siberian Uralic languages 99

Katalin Sipöcz

A word-formational approach to neologisms in modern Northern Mansi

Susanna Virtanen

Word and stem repetitions in the heroic epic songs collected by Antal Reguly ..... 131 Mária Sipos

The use of body part terms in expressing emotions in Udmurt 149

Rebeka Kubitsch

The characteristics of responses given to compliments in Udmurt 173

Zoltán Németh

On some Chuvash-Mari shared lexemes and Agyagási's "Late Gorodets" hypothesis .. 185 Christopher Culver 
“Сувениры Севера" Minority identity and discourse. Representation of indigenous minorities of Northern Russia in the digital media. The case of Dudinka ........... 201 Zsuzsa Várnai and Ágnes Hámori

Reconsidering the Nganasan vowel system 229 László Fejes

New aspects in the study of Mari, Udmurt, and Komi-Permyak: The Typological Database of the Volga Area Finno-Ugric Languages 255 Erika Asztalos, Nikolett F. Gulyás, Laura Horváth, and Bogáta Timár Ethnosyntax in Siberian Uralic Languages (a project report) 275 Bernadett Bíró, Katalin Sipöcz, and Sándor Szeverényi 


\title{
Reconsidering the Nganasan vowel system
}

\author{
László Fejes \\ Hungarian Research Centre for Linguistics, Budapest
}

The description of the Nganasan vowel system has not radically changed after Helimski (1998: 485-486), and his description is quite close to Tereščenko's (1979). The most considerable difference between the two is that Helimski introduced a new category "between" simple vowels and diphthongs: diphthongoid ${ }^{i} a$ (instead of Tereščenko's simple vowel $a$ ) and diphthongoid " $a$ (in addition to the diphthong $u a$ : Tereščenko did not distinguish these two). This distinction is based on (or at least parallel with) Tibor Mikola's fieldwork results, although Mikola suggested that in these cases the articulation gestures before $a$ belong to the preceding consonant, that is, the consonants are palatalized or labialized (Mikola 1970: 60-61).

In this paper, I give an overview of the presentations of the Nganasan vowel system and attempt to ascertain which of the competing views are more adequate for the description of the language. ${ }^{1}$ Moreover, I suggest some modifications which are are without precedent in the history of the research. In Section 1, I present the descriptions and define their differences. In Section 2, I examine whether the distinction of central vowels is phonologically necessary. In Section 3, I explore whether complex vowel constructions should be analyzed as diphthongs and long vowels or as vowel sequences. In Section 4, I reconsider the position of $a$ in the vowel system. Finally, in Section 5, I argue that ${ }^{u} a$ is probably not a phoneme in Nganasan.

\footnotetext{
${ }^{1}$ The observations presented in this paper were made during the research into Nganasan vowel harmony, which was supported by the project Experimental and theoretical investigation of vowel harmony patterns (NKFI 119863) led by Péter Rebrus. I am grateful to Zsuzsa Várnai and Beáta Wagner-Nagy for supporting me with linguistic material and literature and for the joyful discussions of Nganasan phonology. I am beholden to Nóra Wenszky for correcting my English and her advice on structuring my paper - however, of course, I am responsible for all the mistakes remaining in the text. I also thank my anonymous reviewer for their detailed criticism: although, as I will mark several times below, I cannot agree with all their comments, I am much obliged for exploring the inconsistencies and my errors. I would like to express the deepest appreciation to George Soros.

DOI https://10.14232/sua.2021.54.229-253
} 


\section{Introduction: differences in the presentation and the description of the vowel system (1998-2018)}

Although Helimski introduced the new category of diphthongoids into the vowel system of Nganasan, he placed these phonemes into the table presenting the simple vowels (1998: 483): ${ }^{2}$

\begin{tabular}{|l|c|c|c|c|}
\hline & \multicolumn{2}{|c|}{ Front } & \multicolumn{2}{c|}{ Non-front } \\
\hline & Unrounded & Rounded & Unrounded & Rounded \\
\hline High & $i$ & $\ddot{u}$ & $l^{3}$ & $u$ \\
\hline Mid & $e$ & & $\partial$ & $o$ \\
\hline Low & ${ }^{i} a$ & & $a$ & ${ }^{u} a$ \\
\hline
\end{tabular}

Table 1. Nganasan vowels, Helimski (1998)

Diphthongoid is a rarely used term, and (e.g. for English) it usually denotes a long vowel pronounced in a diphthong-like way (where some phonetic quality of the beginning and the end of the vowel differs, but not to such a great extent as usually the quality of the simple vowels of the given language usually does). Although Helimski did not state it explicitly, it seems that his diphthongoids are short vowels which are realized as diphthongs (e.g. $\ddot{a}$ and $\stackrel{a}{a}$-therefore, he listed them among short vowels). Moreover, Helimski suggests about long vowels and his diphthongs that "it is reasonable to treat them as vocalic sequences" (Helimski 1998: 485). Let us notice that if "diphthongoids" are short vowels and "diphthongs" are vowel sequences, it means that Nganasan syllables have no branching nuclei.

Várnai (2000: 33) presents the simple vowels of Nganasan slightly differently:

\begin{tabular}{|l|c|c|c|c|c|}
\hline & \multicolumn{2}{|c|}{ Front } & Central & \multicolumn{2}{c|}{ Back } \\
\hline & Illabial & Labial & Illabial & Illabial & Labial \\
\hline High & $i$ & $\ddot{u}$ & $l$ & & $u$ \\
\hline Mid & $e$ & & $\partial$ & & $o$ \\
\hline Low & ${ }^{i} a$ & & $a$ & & ${ }^{u} a$ \\
\hline
\end{tabular}

Table 2. Nganasan vowels, Várnai (2000)

2 Katzschmann (2008: 318) provides the same system with one irrelevant difference: he changed non-front to back (hintere).

${ }^{3}$ Although different sources mark this vowel with different modified forms of $i$ (I am aware of at least $\ddot{i}, \dot{i}$ and $i$ ), in this article, following Turkish orthography, I will consistently use the simplest possibility, $l$. 
As it is obvious, Várnai introduces a new tongue position into the Nganasan vowel system; however, she does not explain why it is necessary. In addition, she treats Helimski's diphthongs as vowel sequences and calls Helimski's diphthongoids diphthongs (despite this, she presents them among simple vowels). However, she also speaks about long vowels (33-34), which are not treated as vowel sequences, as Helimski suggests, although Várnai's arguments (see below) are applicable to them, too. Nonetheless, later, on page 36, Várnai states that the elements of long vowels, similarly to the elements of vowel sequences, belong to different syllables.

Wagner-Nagy (2018: 48) treats Nganasan simple vowels in a slightly different way again:

\begin{tabular}{|c|c|c|c|c|c|}
\hline & \multicolumn{2}{|c|}{ Front } & Central & \multicolumn{2}{c|}{ Back } \\
\hline & unrounded & rounded & unrounded & unrounded & rounded \\
\hline High & $i$ & $\ddot{u}$ & $l$ & & $u$ \\
\hline Mid & $e$ & & $\partial$ & & $o$ \\
\hline Low & & & & $a$ & \\
\hline
\end{tabular}

Table 3. Nganasan vowels, Wagner-Nagy (2018)

Wagner-Nagy, agreeing with Várnai, calls ${ }^{i} a$ and ${ }^{u} a$ diphthongs and all the other non-simple vowels vowel sequences. Moreover, she also considers Helimski's and Várnai's long vowels to be vowel sequences. Consistently with this analysis, her table of simple vowels does not contain ${ }^{i} a$ and ${ }^{u} a$. Similarly to Várnai, Wagner-Nagy also distinguishes central and back vowels. But while Várnai has no back unrounded vowels, Wagner-Nagy places $a$ into the back unrounded column, and $l$ and $ə$ into the central unrounded column.

The main differences of the above analyses can be summarized as follows: 


\begin{tabular}{|l|c|c|c|}
\hline Difference & Helimski 1998 & Várnai 2000 & W-N 2018 \\
\hline $\begin{array}{l}\text { existence of central } \\
\text { vowel phonemes }\end{array}$ & $X$ & $\checkmark$ & $\checkmark$ \\
\hline $\begin{array}{l}\text { position of } a \text { (= } \iota \text { and } \\
\partial \text { ?) }\end{array}$ & $\boldsymbol{V}^{4}$ & $\checkmark$ & $X$ \\
\hline $\begin{array}{l}{ }^{i} a \text { and } " \\
\text { simple vomong }\end{array}$ & $\checkmark$ & $\checkmark$ & $\checkmark$ \\
\hline $\begin{array}{l}{ }^{i} a \text { and }{ }^{u} a \text { are called } \\
\text { diphthongs }\end{array}$ & $X$ & $\checkmark$ & $\checkmark$ \\
\hline $\begin{array}{l}\text { "long vowels" are } \\
\text { vowel sequences }\end{array}$ & $X$ & $X \checkmark$ & \\
\hline
\end{tabular}

Table 4. Nganasan vowels, systems compared

As we can see, the Wager-Nagy's and Helimski's analyses are always different according to these parameters, while Várnai represents a transition between the two: her description agrees with both Helimski's and Wagner-Nagy's in two parameters, while her description is somewhat inconsistent in the question of "long vowels".

\section{The problem of central vowels}

This problem is relatively simple, since we find no case where the distinction of central vowels were necessary: there are no two otherwise similar vowels between which the only difference is that one is back but the other is central. Várnai's central vowels can be analyzed as unrounded back vowels which are centralized by a redundancy rule. Wagner-Nagy's opinion, namely, that $l$ and $\partial$ are centralized but $a$ is not, can be reconciled with a redundancy rule, according to which non-low unrounded back vowels are centralized.

For the pure satisfaction of being exact, I checked whether Várnai or WagnerNagy refers to the centrality of vowels. I found only one reference: "The stress,

\footnotetext{
${ }^{4}$ The reviewer argues that Helimski (1998) is incomparable from this point of view to the other two grammars since he uses different categories. Nonetheless, the difference between the categorization of unrounded vowels other than $i$ and $e$ is in labeling them similarly, contrary to Wagner-Nagy, who treats them differently.

${ }^{5}$ The reviewer suggests that I misinterpret Várnai's description. According to them, Várnai includes the diphthongs in her table of vowels just because they behave as simple vowels do. However, as I see it, in phonology, the best reason to categorize two surfacially different entities into the same category is that they behave in the same way. Despite that, I can imagine that there are no crucial differences in the analysis of the vowel system behind these differences of presentation.
} 
however, never moves from a high vowel to a central vowel or from a central vowel to a high one" (Wagner-Nagy 2018: 73). Since here central vowels are opposed to high vowels, we must suggest that central is a misprint instead of mid. ${ }^{6}$ Even if it was not the case, central could be replaced by non-low unrounded back without any consequences.

As a conclusion, I argue that it is not reasonable to distinguish central vowels in the Nganasan vowel system.

\section{The problem of diphthongs}

As has been shown before, although Helimski (1998: 485) calls complex vowel structures (except for ${ }^{i} a$ and ${ }^{u} a$ ) diphthongs, he also mentions that "it is reasonable to treat $[. .$.$] them as vocalic sequences". He also sketches some arguments, and many$ other arguments were added by Várnai $(2000,2005)$. In what follows, these arguments are discussed in detail.

\subsection{Length and morpheme boundary}

One argument for the vowel sequence analysis is that Nganasan long vowels and diphthongs are twice as long as a single vowel (Helimski 1998: 485). This must sound strange for a Uralist, since Finnish long vowels and diphthongs are also twice as long or even longer than short vowels (Hakulinen 1941: 22 ${ }^{7}$ ); however, they are not analyzed as vowel sequences in grammars. ${ }^{8}$

\footnotetext{
${ }^{6}$ Beáta Wagner-Nagy confirmed my supposition (personal communication). Nonetheless, the reviewer mentioned that in Wagner-Nagy's two examples, čühənu 'during' and tənini 'there', both contain $\partial$, which is both mid and central. The important point here is that the term is opposed to high (and not front or back). They also lack a citation to Vaysman (2009). There are two main reasons for that. First of all, here I am not interested in stress: I refer to the given locus by Wagner-Nagy only because she mentions central vowels there. The other important reason is that Vaysman's approach is so different from Wagner-Nagy's that it is difficult to compare the two analyses (not to mention the differences of the linguistic data). Although Vaysman (2009: 25-40) writes about the peculiarities of $l$ and $\partial$, these can be referred to as non-low unrounded back vowels even if $a$ is analyzed as a low unrounded back vowel.

7 "Lyhyen ja pitkän vokaalin kestoero suomessa on yhtä jyrkkä kuin yksinäis- ja geminaattakonsonantin: suhde on tavallisesti noin $1: 2$ tai $1: 2^{1 / 2}$, mutta saattaa usein olla jopa $1: 3 . "$ - "The difference between the length of short and long vowels in Finnish is as radical as between simple and geminate consonants: their proportion is usually $1: 2$ or $2 \frac{1}{2}$, but it can be frequently even $1: 3$."

${ }^{8}$ The reviewer interprets my arguments here and below in a way that I compare Nganasan to Finnish, and I suggest that the former should follow the latter. Nonetheless, my approach is completely different. Theoretically, I can imagine that even two different analyses work
} 
Another argument by Helimski (1998: 485, without examples) is that these vowel sequences are often divided by morpheme boundaries; ${ }^{9}$ nonetheless, this is also the case in Finnish, including nominal cases (kala 'fish' : kala-a 'fish-PART' : kala-an 'fish-ILL' - although see also talo- $a$ 'house-PART', in which oa is considered to be a vowel sequence), possessive marking (talo-ssa-an 'house-INE-3'), plural marking (talo-i-ssa 'house-PL-INE'), and past tense in verbal inflection (sano-i 'say-PST.3SG)' etc.

These arguments are not repeated later by other researchers.

\subsection{Number of possible combinations}

Várnai (2005: 116) argues that there would be too many diphthongs (this time, including long vowels) if we did not consider them as vowel sequences. She refers to typological works (Maddieson 1984; Ladefoged and Maddieson 1996) according to which the typical number of diphthongs is under 10: she finds only one language with 22 diphthongs, but she considers the case an error. According to her, there are over 20 vowel sequences in Nganasan (Várnai 2005: 115-116; Várnai 2000: 34; WagnerNagy 2018: 51):

satisfyingly for the same language. However, there are arguments for one kind of analysis (and against another) which refer to some facts of a language (namely, Nganasan) which are also true of another (i.e. Finnish). The only thing I state is that if these were conclusive arguments in the case of Nganasan, they should be the same for Finnish. Even so, not accepting these arguments does not mean that I cannot imagine the analysis of these constructions as vowel sequences, it means only that I cannot exclude the analysis of them as long vowles and diphthongs diphthongs. Additionally, the reviewer states that the length proportion of short and long vowels (diphthongs) is not known - anyway, I just refer to the statement by Helimski.

${ }^{9}$ It remains unclear whether Helimski means that these vowel sequences are usually divided by morpheme boundaries in texts (no statistics included) or that most of them occur only at morpheme boundaries. It seems that the latter is not true, just two of them ( $u i$ and ${ }^{i} a i$ - Várnai 2000: 34; 2005: 115-116; Wagner-Nagy 2018: 50-51) are not attested morpheme internally (in stems). 


\begin{tabular}{|c|c|c|c|c|c|c|c|c|c|c|}
\hline $\mathrm{V}_{1} / \mathrm{V}_{2}$ & $i$ & $\ddot{u}$ & $l$ & $u$ & $e$ & $\partial$ & $o$ & $a$ & ${ }^{i} a$ & ${ }^{u} a$ \\
\hline$i$ & + & $x$ & $x$ & $x$ & $*$ & + & $*$ & + & - & $\div$ \\
\hline$\ddot{u}$ & $x$ & + & $x$ & $x$ & $*$ & + & $*$ & V & - & $\div$ \\
\hline$l$ & $x$ & $\times$ & + & $x$ & $*$ & + & $*$ & + & - & $\div$ \\
\hline$u$ & $(+)$ & $x$ & $x$ & + & $*$ & + & $*$ & + & - & $\div$ \\
\hline$e$ & + & + & - & - & $*$ & $\alpha$ & $*$ & - & - & $\div$ \\
\hline$\partial$ & + & WN & - & + & $*$ & + & $*$ & a & - & $\div$ \\
\hline$O$ & + & - & - & + & $*$ & $\alpha$ & $*$ & + & - & $\div$ \\
\hline$a$ & + & + & - & + & $*$ & $\alpha$ & $*$ & + & - & $\div$ \\
\hline${ }^{i} a$ & $(+)$ & WN & - & - & $*$ & a & $*$ & WN & - & $\div$ \\
\hline${ }^{u} a$ & + & - & - & - & $*$ & $\alpha$ & $*$ & + & - & $\div$ \\
\hline
\end{tabular}

Table 5. Nganasan vowel sequences

Combinations against a darker background are attested. Combinations marked by + occur word internally as well, while sound combinations marked by (+) occur only across morpheme boundaries. The combination ${ }^{\ddot{ }} a$ marked by $\mathrm{V}$ occurs only according to Várnai (2000: 34; 2005: 115), the combinations ä̈, ${ }^{i}$ aü and ${ }^{i} a a$ marked by WN only appear in Wagner-Nagy (2018: 51). The lack of combinations marked by $*, \div, \alpha$ and $\times$ can be explained (see below). Combinations marked by - are absent without evident reason.

Vowels $e$ and $o$ do not occur in non-initial syllables $(*)$; therefore, it is self-evident that they cannot occur as a second vowel of a vowel sequence either. The fact that they do not occur there could be an argument for the stance that these are vowel sequences - however, it is not clear whether vowels restricted to initial syllables can occur as second elements of diphthongs cross-linguistically.

The lack of ${ }^{u} a$ as a second element $(\div)$ is not very surprising, since this element is very rare (however, another explanation will be suggested in section 5 ). This can also be a reason for it to appear only in some combinations. The reason for the lack of ${ }^{i} a$ 
as a second element and its restricted occurrence as a first element is not so selfevident.

The most frequent vowel, $\partial$, occurs only in combination with high vowels and itself (other possible cases: $\alpha$ ). The explanation can be that $\partial$ is fully assimilated in these combinations. Interestingly, Várnai (2000: 43) mentions this, but all of her examples involve high vowels. The explanation can be that the assimilation with high vowels is optional, but it is obligatory in other cases.

Different high vowels are not combined $(\times)$. This is probably a result of a strong harmonic tendency, according to which high vowels assimilate to each other in both roundedness and frontness (cf. Fejes 2019: 110-114).

If we exclude $e, o$ and ${ }^{u} a$ as second elements, 70 possible combinations remain, of which 31 are attested, that means 44\%. For the sake of comparison, in Finnish, according to ISKo $\S 21$, the following combinations are possible:

\begin{tabular}{|l|c|c|c|c|c|c|c|c|}
\hline $\mathrm{V}_{1} / \mathrm{V}_{2}$ & $i$ & $y$ & $u$ & $e$ & $\ddot{o}$ & $o$ & $\ddot{a}$ & $a$ \\
\hline$i$ & + & + & + & + & - & - & - & - \\
\hline$y$ & + & + & $\times$ & - & + & $\times$ & - & $\times$ \\
\hline$u$ & + & $\times$ & + & - & $\times$ & + & $\times$ & - \\
\hline$e$ & + & + & + & + & $*$ & $*$ & - & - \\
\hline$\ddot{o}$ & + & + & $\times$ & $*$ & + & $\times$ & - & $\times$ \\
\hline$o$ & + & $\times$ & + & $*$ & $\times$ & + & $\times$ & - \\
\hline$\ddot{a}$ & + & + & $\times$ & $\div$ & $\div$ & $\times$ & + & $\times$ \\
\hline$a$ & + & $\times$ & + & - & $\times$ & - & $\times$ & + \\
\hline
\end{tabular}

Table 6. Finnish vowel combinations

In Finnish, we have 64 possible combinations, 26 of which are attested in diphthongs: that is about $41 \%$, not crucially different from what we find in Nganasan. However, the Finnish system is much more systematic: the reason for lacking a combination is vowel harmony $(\times)$, a restriction that closing diphthongs cannot end in a mid vowel $(\div)$, non-high (mid) vowels do not combine with each other $(*)$, and 
opening diphthongs must end in a mid vowel of identical roundedness and frontness (otherwise -). (Of course, in some cases these restrictions overlap.) Similarly to Nganasan, the combination of identical vowels is always allowed.

In Finnish, some vowel combinations which do not occur in diphthongs can occur in vowel sequences, that is, when speakers consider them to belong to different syllables. Sometimes suffixation is also an argument to treat these as diphthongs or vowel sequences (see below; sometimes there can be also vacillation, cf. ISKo §22). In Nganasan, it seems that nobody has suggested treating these combinations differently or mentioned vacillation.

The reason for the absence of certain combinations in Nganasan remains unclear. While high vowel $i$ can be a second element after any non-high vowel, $l$ does not occur after any of them. The most problematic issue is that diphthong(oid)s cannot follow any vowel. It can be easily explained if these combinations are treated as diphthongs: triphthongs are prohibited. However, this fact is also accompanied by another phenomenon, i.e. these entities do not occur word initially (cf. Wagner-Nagy 2018: 49-50): diphthong(oid)s can occur only in syllables with a filled onset.

\subsection{Radical consonant gradation}

In radical (or syllabic) consonant gradation some consonants or consonant clusters alternate due to the open or closed nature of the syllable. When the syllable is open, the consonant (cluster) before the vowel is in the so-called strong grade; when it is closed, it is in the so-called weak grade. E. g. basa 'iron, money' : bad'a? 'iron, money-PL' (Várnai 2000: 63-64). According to Várnai (2005: 117), we always find the strong grade before these complex vowel structures. This means that in these cases the expectedly alternating consonant (cluster) is always followed by an open syllable (i.e. by a vowel sequence): kasuə 'cortex' : kasuə? (*kad'uə?) 'cortex-PL'.

However, we find the same phenomenon in Finnish before long vowels and diphthongs: vapaa 'free' : vapaa-n (*vavaa-n) 'free-GEN'; tupakoi-da 'smoke-INF' : tupakoi-n (*tupaoi-n) 'smoke-1SG'; laatikko 'box' : laatikko-on (*laatiko-on) 'boxILL' etc. However, there are also cases when weak grade is used before a diphthong: anto-i(- $\varnothing$ ) 'give-PST(-3SG)' : anno- $i-n$ 'give-PST-1SG'. This kind of behavior can be explained by the fact that some of the long vowels and diphthongs of Finnish have developed from simple vowels of different syllables. Radical consonant gradation is not an active phonological process anymore, it is rather morphologized, sometimes reflecting the phonology of an earlier stage.

This is also true of Nganasan. For instance, Várnai (2000: 64) mentions the phenomenon of reversed consonant gradation. We find weak grade in a word form with an open syllable, but a strong grade in a word form with a closed syllable: $k o \partial u$ 
'storm' : kotu? 'storm-PL'. Therefore, it is strongly questionable whether radical consonant gradation can be an argument in this debate. ${ }^{10}$

\subsection{Rhythmical consonant gradation}

Rhythmical consonant gradation is typical of suffixes: consonants are in the strong grade in even syllables (i.e. after stems with an odd number of syllables) and in the weak grade in odd syllables (i.e. after stems with an even number of syllables): $n \iota-t \imath$ 'wife-3SG', тәпи-ди 'egg-3SG', bakипи-tu 'sturgeon-3SG', kaana?a-ðи 'creek-3SG' etc. (Várnai 2000: 62). As the last example shows, $a a$ has to be counted as two syllables to get four syllables in the stem.

Earlier Hajdú $(1962,1964)$ suggested that this kind of phenomenon can be explained by mora counting: short vowels count as one mora, while long vowels and diphthongs count as two moras. Várnai (2005: 125) suggests that instead of counting moras it is enough to count syllables, if we speak about vowel sequences instead of long vowels and diphthongs. However, it seems that neither mora counting nor syllable counting is a superior solution to the other. ${ }^{11}$

Moreover, there are some cases which show that the number of syllables is not the only factor which can affect rhythmical consonant gradation. For us, the most important fact is that vowel sequences are always followed by the weak grade, even if the stem has an odd number of syllables: latəə-ðu 'bone-3SG', kümaa-ðu 'knife3SG', kиһиə-ðu 'skin-3SG' etc. (Várnai 2000: 63). This phenomenon cannot be explained by interpreting these complex vowel structures either (i) as long vowels and

\footnotetext{
${ }^{10}$ The reviewer does not agree with my conclusions and argues that the system of gradation did not collapse in Nganasan as it did in Finnish. As an argument, they refer to the fact that some speakers apply the rules of (radical) consonant gradation even in Russian loanwords. However, this is also true of Finnish: some loanwords obey the rules of consonant gradation (netti 'netSG.NOM' : neti- $n$ 'net-SG.GEN') and even introduce new types of gradation (of consonants occurring only in loanwords, cf. bloga-ta 'blog-INF' : bloggaa-n 'blog-1SG'). This phenomenon does not inevitably confirm that gradation is active phonologically. Instead, it can be analyzed as the loanword's adaptation to the existing morpho(phono)logical patterns of the language.

${ }^{11}$ After my presentation Tapani Salminen referred to the Occam's razor principle, saying that syllable counting is better than mora counting, because we do not have to adduce moras: the simpler analysis is always better. Then I had to agree with this argument, but now I think Occam's razor can also cut in the opposite direction. Since phonetically we have long vowels and diphthongs, it is an obvious and straightforward solution to treat them as long vowels and diphthongs in phonology as well, and to refer to their length (moras) when it is needed. Supposing a different phonological structure when it is not really needed is superfluous - or, at least, neither of the two solutions can be considered more complicated than the other one.
} 
diphthongs or (ii) as vowel sequences. Another fact is that we can always find the strong grade after consonant-final stems, including those which are vowel-final on the surface but a stem final consonant-like element (called quasi-nasal by Várnai 2000: 63, quasi-consonant by Várnai 2010, and empty slot by Wagner-Nagy 2018: 67, etc.) can be found: koðu-tu 'storm-PL'. Anyway, this kind of element has to be assumed because rhythmical consonant gradation is not a purely phonological phenomenon in contemporary Nganasan, and we have to introduce historical elements to account for some morphologized phenomena as a part of contemporary phonology.

Although Finnish used to have rhythmical consonant gradation as well, it has just traces of it now. Thus, in contemporary Finnish there is no phenomenon comparable to Nganasan rhythmical consonant gradation.

\subsection{Transparency in vowel harmony}

In Nganasan, high vowels following each other strongly tend to agree in frontness/backness (front/back vowel harmony). However, in the following cases,

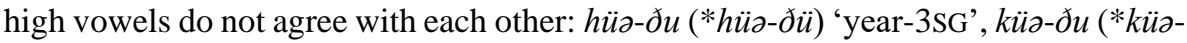

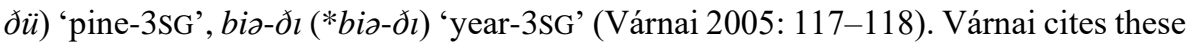
examples as arguments in support of treating complex vowel structures like $\ddot{u}$ or is as vowel sequences. According to her, if $\ddot{u} \partial$ and $i \partial$ were diphthongs, vowel harmony should work here. The preconception in this argumentation is that even if a vowel (in this case $ə$ ) is opaque as the nucleus of a syllable, it must be transparent as a second element of a diphthong. ${ }^{12}$

However, this preconception is not supported by any fact. Moreover, we can cite examples from Finnish which contradict this assumption. Although Finnish has no opaque neutral vowels in vowel harmony, there is another kind of phonological phenomenon which indicates something else. One group of the allomorphs of the illative case is $-h V n$, in which $\mathrm{V}$ is identical to the vowel before $h$ : $t \ddot{a}$-hän 'this-ILL', dialectal/archaic koulu-hun 'school-ILL'. In Modern Standard Finnish, this ending usually occurs after long vowels and diphthongs, and in the latter case $\mathrm{V}$ is identical to the second element of the diphthong: työ-hön (*työ-hyn) 'work-ILL', töi-hin (*töihön, *töi-hyn) 'work.PL-ILL'. As these cases show, the height of $y$ in the first example

\footnotetext{
12 The reviewer wonders why this preconception is necessary in this argumentation. Actually, it seems to be clear for me that if someone uses a phenomenon as an argument in favor of analyzing an element as something, they inevitably must think that the given phenomenon could not work in the same way if the element was analyzed differently. Additionally, Várnai (2005: 117) herself writes: "if the two adjacent vowels belonged to the same syllable (if they constituted a diphthong), vowel harmony would be expected to apply". As I demonstrate below, this is not the case.
} 
or the labiality (and again, height) of $\ddot{o}$ in the second example do not affect the vowel of the suffix. The behavior of the second element of a diphthong and a vowel in a syllable nucleus is not different when locality plays a role. This can be the case in Nganasan as well; therefore, the above mentioned forms cannot be used as arguments in the debate about long vowels and diphthongs vs. vowel sequences.

\subsection{Syllable structure}

In many languages, the complexity of syllable structure is restricted. This can mean that when the nucleus is branching, the code cannot be filled or cannot be branching. This provides a promising method $^{13}$ to decide which structures are diphthongs (long vowels) in Nganasan:

If the distribution of short vowels is similar to that of ${ }^{i} a$ and ${ }^{u} a$ but differs from that of others, we have to speak about "diphthongoids" and diphthongs.

If the distribution of short vowels differs from that of ${ }^{i} a$ and ${ }^{u} a$ but is similar to that of others, then we have to speak about diphthongs and vowel sequences.

A statistical evaluation of the material in Brykina et al. $(2016)^{14}$ gave the following results:

${ }^{13}$ To my knowledge, nobody has ever tried to use this method to inspect this problematic field of Nganasan phonology.

${ }^{14}$ The reviewer criticizes me for using the corpus with such methods. They argue that the material of the corpus (and any earlier materials on Nganasan!) cannot be used for phonetic or phonological investigations, because the transcription is neither phonetic or phonological. This kind of argumentation raises several issues. First of all, any current or earlier study of Nganasan phonology can be criticized similarly. Additionally, phonological analysis must precede a phonological (phonemic) transcription: there is no phonemic transcription until the phoneme inventory is specified (including allomorphy). Analysis and transcription are always in interaction: they overwrite each other. According to the reviewer, I should have checked the sound material. However, not being an expert of Nganasan, I do not consider myself competent to correct the transcription of the fieldworkers, and it would hardly be convincing if I did that. Moreover, I could be criticized for not doing phonetic measurements - and if I did that, it would be another paper. To sum up: I am aware of the limits of my investigation and I do not use the corpus because I believe that it is completely reliable, but because that is the most comprehensive and best researchable source available. 


\begin{tabular}{cccc|c} 
nucleus/coda & empty $(\varnothing)$ & simple $(\mathbf{C})$ & branching (CC) & $\emptyset: \mathbf{C}$ \\
\hline $\mathbf{V}$ & 18,335 & 5,906 & 24 & 3.1 \\
\hline${ }^{i} \boldsymbol{a},{ }^{u} \boldsymbol{a}$ & 715 & 368 & 0 & 1.95 \\
\hline $\mathbf{V V}$ & 3,237 & 1,113 & 0 & 2.9 \\
\hline $\mathbf{V}:{ }^{\boldsymbol{i}} \boldsymbol{a},{ }^{\boldsymbol{}} \boldsymbol{a}$ & 25.6 & 16 & - & \\
\hline $\mathbf{V}: \mathbf{V V}$ & 5.7 & 5.3 & - & \\
\hline
\end{tabular}

Table 7. The distribution of vowels (diphthongs, vowel sequencies etc.) in different syllable structures

First of all, we have to conclude that branching codas are practically unknown in Nganasan (cf. Várnai 2000: 39, Wagner-Nagy 2018: 66). All the words with branching codas attested in the corpus are foreign words (most frequently maskvaa maskvaa 'Moscow') or typos. (Nonetheless, there is neither branching onset nor branching coda at the word periphery in native Nganasan words. Therefore, it is impossible to decide whether it is the onset or the coda branching inside this kind of loanwords.)

It is salient that the distribution of V and VV is very similar: in both cases, every fourth example is followed by a consonant. (Or, every fifth or sixth coda is preceded by VV, independently of whether they are filled or not.) This suggests that VVs are vowel sequences, since their distribution is similar to that of simple vowels. In this case, we have to suppose that the second element is in a different syllable, and this is the reason why it is followed by a consonant in the same proportion as any other vowel. In this case, we expect that ${ }^{i} a$ and ${ }^{u} a$ are diphthongs, and therefore they will be followed by a coda more rarely than simple vowels. However, the case is the opposite: these sounds are followed by a coda in every second case. Therefore, these statistics do not prove anything.

We have to conclude that the complexity of the nucleus does not restrict the complexity of coda in Nganasan. Therefore, this method cannot be used to decide whether Nganasan has a rich system of long vowels and diphthongs or vowel sequences. 


\subsection{Conclusion}

To sum up, despite the fact that current literature on Nganasan phonology states that there are vowel sequences in Nganasan, there is no conclusive argument which would decide whether these are really vowel sequences or diphthongs and long vowels. It is also questionable whether this is a crucial problem of Nganasan phonology. It plays the most important role in the description of rhythmical consonant gradation, and even there both can work to the same extent. However, rhythmical consonant gradation is not an active phonological process but rather a morhologized regularity, which more or less reflects the phonology of an earlier stage in the history of the language.

The currently accepted analysis with vowel sequences causes two different kinds of problems. On the one hand, according to the analysis with vowel sequences, Nganasan has a lot of hiatus, although vowel initial words are rare (Wagner-Nagy 2018: 49). Cross-linguistically, even languages in which vowel initial words are common tend to avoid hiatus and use different kinds of strategies to resolve them (mainly throught the deletion of one of the vowels or consonant epenthesis). On the other hand, if we analyze Nganasan complex vowel structures as vowel sequences, it would be consistent to do so with the similar Finnish ones. However, the necessity of this kind of analysis has never emerged in Finnish phonology. Anyway, I cannot see such crucial differences between the phonetic and phonological phenomena of Finnish and Nganasan that they should have to be analyzed in such a radically different way.

\section{The problem of $a$}

Nganasan has two kinds of vowel harmony. One is the already mentioned front/back harmony, which is quite regular but restricted to high vowels. In suffixation it is active only when the other kind of harmony is active as well. This other kind of harmony can be called quasi-labial, and it works throughout Nganasan morphophonology, however, with many exceptions and irregularities (see Fejes 2018a; Fejes 2018b). It can be called quasi-labial because one of the harmonic classes contains rounded vowels and $a$ (bolded in Table 8), the other contains unrounded vowels (except for $\partial$, which does not belong to any of the classes; underlined in Table 8):

\begin{tabular}{|l|c|c|c|c|}
\hline & \multicolumn{2}{|c|}{ Front } & \multicolumn{2}{c|}{ Back } \\
\hline & Unrounded & Rounded & Unrounded & Rounded \\
\hline High & $\underline{i}$ & $\ddot{\boldsymbol{u}}$ & $\underline{l}$ & $\boldsymbol{u}$ \\
\hline Mid & $\underline{e}$ & & $\partial$ & $o$ \\
\hline Low & & & $a$ & \\
\hline Diphthongs & $\underline{i} a$ & & & ${ }^{u}$ \\
\hline
\end{tabular}

Table 8. Harmonic classes in Nganasan 
This suggests that, although $a$ is phonetically unrounded, phonologically it belongs to the rounded vowels. There is no known phonological phenomenon in Nganasan which would support that it is a phonologically unrounded vowel. Since in the case of low vowels roundedness does not have such a strong distinctive power as in the case of higher vowels, a redundancy rule causing a low vowel to become unrounded is not very strange. Therefore, the vowel system should look like this:

\begin{tabular}{|l|c|c|c|c|}
\hline & \multicolumn{2}{|c|}{ Front } & \multicolumn{2}{c|}{ Back } \\
\hline & Unrounded & Rounded & Unrounded & Rounded \\
\hline High & $\underline{i}$ & $\ddot{u}$ & $\underline{l}$ & $u$ \\
\hline Mid & $\underline{e}$ & & $\partial$ & $o$ \\
\hline Low & & & & $a$ \\
\hline Diphthongs & $\underline{i}$ & & & ${ }^{a} a$ \\
\hline
\end{tabular}

Table 9. Harmonic classes in Nganasan with a analyzed as rounded

However, if ${ }^{i} a$ and ${ }^{u} a$ are analyzed as simple vowels realized in a diphthong-like way, we get a system with two low rounded back vowels:

\begin{tabular}{|l|c|c|c|c|}
\hline & \multicolumn{2}{|c|}{ Front } & \multicolumn{2}{c|}{ Back } \\
\hline & Unrounded & Rounded & Unrounded & Rounded \\
\hline High & $\underline{i}$ & $\ddot{\boldsymbol{u}}$ & $\underline{l}$ & $u$ \\
\hline Mid & $\underline{e}$ & & $\partial$ & $o$ \\
\hline Low & $\underline{i} a$ & & & $a,{ }^{u} a$ \\
\hline
\end{tabular}

Table 10. Harmonic classes in Nganasan with a analyzed as rounded and diphthons analyzed as monophthongs underlyingly

Does this mean that ${ }^{i} a$ and ${ }^{u} a$ must inevitably be analyzed as diphthongs? To answer this question, it is worth taking a closer look at the distribution of ${ }^{u} a$.

\section{The problem of ${ }^{u} a$}

To decide whether ${ }^{u} a$ must be considered to have phonemic status in Nganasan, we have to take a closer look at its distribution. Since it occurs most of the time after $h$ where it also alternates with $a$, which almost never occurs after $h$, in Section 5.1 I concentrate on the distribution of $a$ and ${ }^{u} a$ after $h$. In Section 5.2, I overview the cases when " $a$ occurs after consonants other than $h$. In Section 5.3, I sum up the facts on the distribution of ${ }^{u} a$ and argue that it is not a phoneme in Nganasan. 


\subsection{The distribution of $a$ and ${ }^{u} a$ after $h$}

The ${ }^{n} a$ element seems to be in an almost perfect complementary distribution with $a$ after $h$. Wagner-Nagy (2018: 85) writes: "[t]he consonant and vowel combination /ha/ exists only in one word, taharia 'now' which is an old loanword from Russian (taperja 'now'). In other words, /ua/ appears in this position, and the sound combination is pronounced as [hwa] [...]". The loanword must be considered old, since Russian $p$ is reflected by Nganasan $h$ due to the $p(>f)>h$ change. (The $f$ state is attested in Castrén's materials, cf. e.g. Helimski 1998: 484-485.) The vowel $e$, following the original $p$, is atypical in non-initial syllables in Nganasan. We could expect that it is substituted by the only mid vowel possible in a non-initial syllable, a, but the ha sequence seems to be prohibited as well: “/h/: There are no data for a $/$ ha/ sequence. /ha/ only appears in one word, taharia, which is an old loanword from Russian. The sequence /he/ is attested in the word-initial position" (Wagner-Nagy 2018: 59). Nonetheless, the statement about the absence of $h$ s seems to be a mistake, since both Brykina et al. (2016) and even Wagner-Nagy (2018) give several words containing

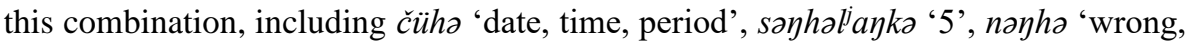
bad', həkəgəə 'warm' etc. However, although tahar'a occurs several times and in different forms in Brykina et al. (2016), it has no form with a vowel other than $a$ after $h$. (The most frequent form of it is taharia $a$, which is the second most frequent word form of the whole corpus: only to 'well' is more frequent (by $\sim 30 \%$ ), and it is more frequent (by $\sim 60 \%$ ), than the third most frequent tati 'that'.)

Another remarkable fact is that Helimski (1998: 485) mentions that even his elderly female informants pronounced labial fricatives ([f] or $[\phi])$ or labiovelar $[\mathrm{hw}]$ instead of $[\mathrm{h}]$. This suggests that originally $h$ was labialized, and delabialization happened everywhere but before $a$. In this case, we must suppose that either the emergence of the second $a$ in tahar $a$ is relatively late and earlier another vowel stood after $h$, or we have a case of irregular delabialization. In any case, it remains unclear why such a sequence, atypical for Nganasan, has developed.

In Brykina et al. (2016), we find some other cases of ha combinations. However, these are all in words of Russian origin, predominantly proper names (and even the possibility of code switching cannot be excluded). In all these cases, the source of $h$ in the original Russian word is [x].

Despite these facts, we can consider " $a$ an allophone of $a$ after $h$, mainly because of its alternations. In consonant gradation, $b$ alternates with $h$, and when $b$ is followed by $a$ in the weak grade allomorph, $h$ is always followed by ${ }^{n} a$ in the strong grade (see the allomorphs of the so-called renarrative mood suffix in Helimski 1998: 489). However, it must be pointed out that sometimes we find $a$ after $h$ in some suffixes in Brykina et al. (2016): 
bəðй-hatu grow(intr)|вырасти-INFER.[3SG.S]

basa-han-sa hunt|охотиться-INTENT-INF

d'üəra-lu-tə-baha-ndə? paint|краска.[VBLZ]-PASS-IPFV-NAR-3PL.R

However, we can find identical or very similar word forms in which ${ }^{u} a$ is an allophone of $a$ after $h$ :

tuj-hйatu come|прийти-INFER.[3SG.S]

basa-hüan-sa hunt|охотиться-INTENT-INF

d'üəra-lu-tə-bahũa-ndə? paint|краска.[VBLZ]-PASS-IPFV-NAR-3PL.R

Therefore we must suppose that these forms with ha are typos, slips of the language consultant's tongue, or alternative but rare realizations of $/ \mathrm{ha} /$.

\subsection{The occurrence of ${ }^{u} a$ after consonants other than $h$}

In some cases, ${ }^{u} a$ is also attested after consonants other than $h$. However, the number of such consonants is relatively small. In Table 11 below, I show some data on the distribution of some vowels (including diphthong(oid)s) after different consonants from Brykina et al. (2016). Items are ordered according to frequency. The first column contains the vowel, the second shows the number of occurrences, the third displays after how many different consonants it is attested, while the fourth and fifth show which the most frequent consonant preceding the vowel is, and how many times it occurs before the vowel. The last column shows the proportion of the cases in which the most frequent consonant (column 4) precedes the vowel out of the cases when the given vowel occurs. 


\begin{tabular}{|c|c|c|c|c|c|}
\hline Vowel & $\sum$ & Cs & most freq. & times & \% \\
\hline$a$ & 9,454 & 23 & $t$ & 1,943 & $21 \%$ \\
\hline$u$ & 5,257 & 20 & $t$ & 1,263 & $24 \%$ \\
\hline$a$ & 4,760 & 32 & $m$ & 613 & $13 \%$ \\
\hline$i$ & 4,667 & 25 & $n$ & 467 & $10 \%$ \\
\hline$l$ & 3,390 & 17 & $t$ & 825 & $24 \%$ \\
\hline$\ddot{u}$ & 3,294 & 20 & $t^{\prime}$ & 423 & $13 \%$ \\
\hline$o$ & 1,338 & 20 & $k$ & 466 & $35 \%$ \\
\hline$e$ & 899 & 19 & $d, n$ & 199 & $22-22 \%$ \\
\hline${ }^{i} a$ & 788 & 19 & $?$ & 199 & $25 \%$ \\
\hline${ }^{u} a$ & 389 & 8 & $h$ & 265 & $68 \%$ \\
\hline${ }^{l} a$ & 63 & 2 & $?$ & 61 & $98 \%$ \\
\hline${ }^{u} a$ & 34 & 8 & $\partial$ & 12 & $35 \%$ \\
\hline${ }^{u} \partial$ & 8 & 2 & $h$ & 5 & $63 \%$ \\
\hline$\ddot{u}_{\partial} \partial$ & 3 & 1 & $?$ & 3 & $100 \%$ \\
\hline${ }^{l} \partial$ & 2 & 1 & $?$ & 2 & $100 \%$ \\
\hline$a^{i}$ & 1 & 1 & $?$ & 1 & $100 \%$ \\
\hline$\partial^{i}$ & 1 & 1 & $?$ & 1 & $100 \%$ \\
\hline
\end{tabular}

Table 11. The number and distribution of vowels (including diphthongs) in the Nganasan corpus

The number of consonants in the third column can be over 21 , the number of consonant phonemes in Nganasan (e.g. Wagner-Nagy 2018: 34), because the corpus also contains foreign words not adapted to Nganasan phonology. The vowels under the row of ${ }^{u} a$ are considered to be allophones of $a,{ }^{i} a$ or ${ }^{u} a$. Wagner-Nagy (2018: 48) states that ${ }^{\ddot{ }} a$ occurs after palatal consonants. This, however, is certainly not justified by the data in the corpus: ${ }^{\prime \prime} a$ occurs twice after $d$ ' and once after $t$ ', but after non-palatal consonants in all other 31 cases. Wagner-Nagy (2018: 49) also states that ${ }^{u} a$ can be

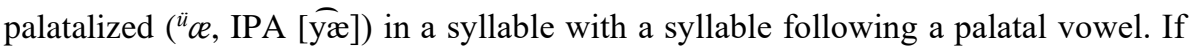
we accept that ${ }^{\ddot{ }} a$ in the corpus indicates these cases, this seems to be true for all of the cases, except for the stem $b \partial n^{\ddot{u}} a$ - 'stretch oneself'.

In stems, ${ }^{u} a$ occurs after stops and sonorants. However, in most cases, we can find the same stems with $u$, or more rarely, $a$ or $u a$ instead of ${ }^{u} a$.

$d:$

kund ${ }^{u} a$ - 'sleep, fall asleep' occurs 27 times, but we also find kundu-kə-ta-ðə ' ITER-PRS-3SG.R' beside $k u n d^{u} a-k \partial-t u$ ' -ITER-PRS.[3SG.S]'; 
ð:

bəð $a$ - 'grow (intr-tr)' 5 times, but also bətu-baðu- $\eta$ 'grow(tr)-INFER-2SG.S' twice;

$t$ :

d'omt $a$ - 'fight' 10 times, but also d'omta-, d'omtu- (7 and 10 times, respectively), kobt ${ }^{u} a$ - 'girl' (over 150 times), also kobtu-P' $a$, 'girl-AUG' (7 times), t'et" a 'very' (34 times), also t'etua 'very' (24 times);

$k$ :

tojk $k^{u} a$ - 'be in difficulty' (once) and tajk $k^{u} a t u$ - 'hindrance' (once), but also tojku- 'be in difficulty' (once)

$k^{u} a d^{\prime} a-$ 'fresh' (once), but also kuańd'a- 'fresh' (3 times);

$l$ :

bəl'at'a- baluat'u- 'become angry' (once both), bəl'aðatəgibtü- 'get angry' (twice);

$n:$

$\tan ^{u} a$ - 'few' (once), also tanə- (4 times);

$r:$

hor ${ }^{u} a$ - 'take up, deal with' eight times, also hora- for times (once even horu-, but without meaning): horua-tuə 'take up-PTCP.PRS[NOM.SG]' but horu-tuə-gümü-? ' -PTCP.PRS-EMPH-NOM.PL', cf. also horuabutz- 'sort out' but horuəbtu?tə'have floors',

$m ә r^{u} a$ - 'break' (tr: ломать) once: once also mәru- 'break' (intr: сломаться).

It seems that there is only a very restricted set of consonants after which we find ${ }^{u} a$; even in those forms, ${ }^{u} a$ occurs just in a very few (one to three) stems after the given consonant. Even in these stems we can observe more or less vacillation between ${ }^{u} a$ and some other vowels or vowel sequences.

I have to mention here that the reviewer strongly doubts that some of the data above really prove vacillation. According to them, kund $a$ - ('sleep'; Kosterkina et al. 2001, 72: кундуаса 'спать') and kuntu- (: kundu-) ('fall asleep'; Kosterkina et al. 2001, 72: кундудя 'заснуть') are two different verbs. Nonetheless, while kundu- and kuntu- (and also kunda-) are consistently tagged as 'fall.asleep' in the corpus, kund ${ }^{u} a-$ is tagged 16 times as 'sleep', and 10 times as 'fall.asleep'. This suggests that vacillation is attested at least in the meaning 'fall asleep'. Wagner-Nagy (2018: 427, 510) also cites examples of the $k u n d^{u} a$ - stem with the glossing 'fall asleep', although I see also the glossing 'sleep' as acceptable in the given sentences.

The reviewer also states that the corpus evidently handles bəð $\partial^{u} a$ - 'grow (intr-tr)' and batu- 'grow (tr)' as two different verbs. However, the latter occurs twice, and the former twice as intransitive and three times as transitive. Therefore, it does not seem to be evident that these are two different verbs. According to Kosterkina et al. (2001), 
ьә $\check{\partial}^{u} a$ - (29: бәзуаса) is intransitive and bətu- (34: бәтудя) is transitive. I also have to mention that Wagner-Nagy in some cases (2018: 96, 515 three times) writes bəðuaspeaking about the action noun bəðuamu 'growing' (which I could not attest in the corpus).

According to the reviewer, the forms d'omt ${ }^{u} a-$, d'omtu- and d'omta- belong to two different verbs again. Nonetheless, this does not seem to be evident. The form d'omtuis glossed as 'scold' in five cases and as 'fight' in two cases, while the forms d'omtaand $d^{\prime o m t} t^{u} a$ - as 'fight' in all the cases. Kosterkina et al. (2001: 45) contains only d'omt ${ }^{u}$ - (дөмтуаса) and gives both meanings.

The reviewer also doubts, based on the sound records, that the augmentative suffix is present in the forms written as kobtu-P ${ }^{u} a$. I leave this question open: I hesitate to believe that a non-existent suffix is written seven times. They also remark that all the seven forms occur in one and the same text, so it can be a personal variant. However, I believe that even individual language use can reflect the general characteristics of language, cf. how a feature of phonology can be attested even in a form with specific morphology. They also add that other augmentative forms of the word are more frequent: it is true that $k o b t^{u} a$-rba?a occurs 16 times unsuffixed and 4 times with other suffixes, and $k o b t^{u} a-n a ? a$ also exists, but I cannot see its relevance to the case (and to the existence) of kobtu-Pu $a$.

The reviewer states that the forms t'et" $a$ 'very' and tetua are just traditional forms of recording, and most likely just one of them is correct, although it is difficult to decide which one. However, according to the descriptions, these two should be distinguishable based on the phonetic facts. Mikola (1970: 60) states that ${ }^{u} a$ sounds (and, according to him, should be analyzed) as a sequence of a labialized consonant and a vowel $a$. Várnai (2000: 40-41) and Wagner-Nagy (2008: 49) also claim that the first element of the allomorphs of ${ }^{u} a$ is very short and even likely to remain unpronounced, or its liability can surface on the preceding consonant or on the second half of the diphthong (differently in different environments). In addition, Helimski (1998: 485) states that vowel sequences are twice as long as simple vowels. Várnai (2005: 119) writes that "in casual pronunciation, diphthongs alternate with short vowels, whereas vowel clusters alternate with long vowels" (on the next page arguing that there are no long vowels in Nganasan, just clusters of two identical vowels, so this must be understood as different vowels immediately following each other being able assimilate to each other). If these statements are all correct, ${ }^{u} a$ and $u a$ should be phonetically well distinguishable. If they are not, then we must suppose that the reason for the inconsistency is that 'very' is a word that cannot be suffixed. Thus, it cannot be attested whether it behaves like a simple vowel or not. In that case, the question is whether there is a real difference in the pronunciation of the suffixable stems, or the decision between recording ${ }^{u} a$ or $u a$ is simply based on morphophonological analysis. 
According to the reviewer, one of $k^{u} a{ }^{\prime} d^{\prime} a$ - and kuan'd'a- is simply an inconsistency in transcription. However, they do not say which of these should be wrong. The form kuan'd'a- occurs only once, but it is much more possible that the diphthong marker diacritic sign was left out by mistake. They also accuse me that I do not take into consideration the possibility of typos. I definitely do - however, when I found that in every instance when " $a$ follows a consonant other than $h$, there is also a similar form with $u, a$ or $u a$ instead of ${ }^{u} a$, it does not seem to be the most probable possibility that these are all typos.

We must suppose that at least in a part of the cases, when the corpus contains a form with ${ }^{u} a$, the informant pronounced a vowel without labialization. Wagner-Nagy (2018: 49) writes: "[t]he pronunciation of [ua $]^{15}$ is rather varied, it may be realized as [e], e.g. kabtu? $\widehat{\text { ua }}$ [koptu?e] 'went out [fire]' or even as [ $\Lambda$ ], e.g. tanúamsa [tan $\Lambda$ msa] or [tanamsa] 'get used to'." The question is whether the diphthong is simplified in these cases, or (a) simple vowel(s) has/have a diphthong-like allophone. The latter seems to be less favorable if we take it into account that these supposed allophones occur just in a small set of stems, and there is no clearly identifiable environment in which they arise. The former seems to be unlikely since the supposed phoneme is extremely rare, its primary realization is more frequent as a secondary realization of another phoneme.

As for suffixes, there is only one form, $-P^{u} a$, with the vowel ${ }^{u} a$. The suffix appears in two positions after nominal stems and after postpositional stems, being an augmentative suffix (AUG in the corpus) after the former and both an adverbalizer (ADVZ.STEM) or a lative pronominalizer (LATPRON). The distribution of the different forms of these suffixes exhibits some difference. For the augmentative suffix, the allomorph $-? a$ is the most usual form, but sometimes $a$ is changed into a diphthong: in most cases, the vowel preceding the glottal stop seems to be copied after it, before $a$. The form $-P^{u} a$ occurs exclusively after stem final $u$, cf. kobtu- $P^{u} a$, 'girl-AUG' above. However, this kind of assimilation does not seem to be obligatory, since there are at least two cases in the corpus with a: d'üntuu-?a 'middle-AUG' (twice) and muyku-?a 'tree-AUG'.

In the case of the adverbalizer (19 times) and the lative pronominalizer (15 times), the suffix seems to be even more regular:

$-P^{u} a$ after $u$,

- $P^{i} a$ a after $i$ and $l$,

$-P^{l} a$ a after $l$,

-?a after $a$.

${ }^{15}$ Supposedly a typo, instead of / $\widehat{\mathrm{ua}} /$. 


\subsection{Conclusion}

It has been demonstrated that there are only some restricted cases when ${ }^{u} a$ occurs in Nganasan. Most frequently, both in stems and suffixes, it is attested after $h$, where it is in an almost perfect complementary distribution with $a$. The emergence of ${ }^{u} a$ after $h$ is historically clear, basically, the labiality of the consonant has been moved to the following vowel. The only problematic issue is that of $\operatorname{tahar}^{i} a$, but it is not enough to reject the analysis of ${ }^{u} a$ after $h$ as an allophone of $a$.

In suffixes, ${ }^{u} a$ also occurs after $?$. In these cases it is clearly an allomorph of $a$, which has even an allomorph ${ }^{l} a$ in such position (cf. Wagner-Nagy 2018: 48).

In stems, ${ }^{u} a$ also occurs after some stops and sonorants, but the number of stems in which it occurs is very low, and even then we can find vacillation between ${ }^{u} a$ and other vowels or the vowel sequence $u$. These cases are far from unproblematic, since we find no explanation for this kind of allophony. Nonetheless, if we analyze ${ }^{u} a$ in these stems as a phoneme, it will be an extremely rare phoneme, the realization of which is much more frequent as a secondary, allophonic realization of another phoneme. In addition, the emergence of ${ }^{u} a$ in these environments lacks historical explanation.

Moreover, we are not aware of any minimal pairs in which one word contains an ${ }^{u} a$ and a similar word contains another simple vowel, diphthong or vowel sequence in the same position, and their meanings differ.

To sum up, we do not have enough supporting evidence for ${ }^{u} a$ being a phoneme, and, at the moment, it seems to be much more likely that we can find an explanation for allophony in the future than convincing arguments to treat it as a phoneme.

\section{A modest proposal}

Based on the above, the case of central vowels (2) is the most evident: we need no distinction of central vowels in Nganasan, centrality is just a phonetic feature of (nonlow?) unrounded back vowels.

The phonemic labiality of $a$ (4) also seems to be unambiguous, at least until we discover some phonemic regularities which show that $a$ sometimes behaves like unrounded vowels. However, two problems arise in connection with this. On the one hand, if we want to treat $a$ as a phonetically central vowel, we have to order redundancy rules in a way that a first delabializes and then centralizes. If we want to see $a$ as a phonetically back vowel, we have to apply the rules in the reverse order. On the other hand, if seeing the high number of irregularities and unusual behavior in quasi-labial harmony, we decide to treat this phenomenon as reflecting earlier but not any more active phonological processes (cf. Fejes 2018: 68), the analysis of $a$ as a labial vowel is not justified anymore. 
The deletion of ${ }^{u} a$ from the phonemic inventory (5) - independently of the fact whether we analyze it as a diphthong, a simple vowel realized in a diphthong-like way or anything else - is much more problematic, but in general well-founded. In most of the cases ${ }^{u} a$ shows a clearly allophonic distribution, and there are only a handful of stems where we have no clear explanation for allophony. However, it is not enough to analyze it as a phoneme.

Finally, the problem of diphthongs-or-vowel-sequences (Section 3) is far from evident. The only thing which is worth emphasizing is that present-day mainstream literature on Nganasan phonology unequivocally supports the vowel sequence analysis, although this analysis is not unquestionably better than the other one involving diphthongs. The main issue is the inconsistency with mainstream Finnish phonology: to accept the vowel sequence analysis entirely, either we have to show the crucial differences between Nganasan and Finnish phonology which support the different analysis, or we have to rewrite Finnish phonology.

To sum up, I recommend the following table to present the Nganasan vowel system:

\begin{tabular}{|l|c|c|c|c|}
\hline & \multicolumn{2}{|c|}{ Front } & \multicolumn{2}{c|}{ Back } \\
\hline & Unrounded & Rounded & Unrounded & Rounded \\
\hline High & $i$ & $\ddot{u}$ & $l$ & $u$ \\
\hline Mid & $e$ & & $\partial$ & $o$ \\
\hline Low & $\left.{ }^{i}{ }^{i} a\right)$ & & & $a$ \\
\hline
\end{tabular}

Table 12. Nganasan vowels - a proposal

$\begin{array}{ll}\text { Abbreviations } \\ 3 & \text { 3rd person possessive suffix } \\ \text { 3SG } & \text { 3rd person singular possessive/verbal suffix } \\ \text { ADVZ.STEM } & \text { adverbializer } \\ \text { AUG } & \text { augmentative } \\ \text { EMPH } & \text { emphatic } \\ \text { ILL } & \text { illative } \\ \text { INE } & \text { inessive } \\ \text { INF } & \text { infinitive } \\ \text { INFER } & \text { inferential } \\ \text { INTENT } & \text { intentional } \\ \text { IPFV } & \text { imperfective } \\ \text { ITER } & \text { iterative }\end{array}$




$\begin{array}{ll}\text { LATPRON } & \text { lative pronominalizer } \\ \text { NAR } & \text { narrative } \\ \text { NOM } & \text { nominative } \\ \text { PART } & \text { partitive } \\ \text { PASS } & \text { passive } \\ \text { PL } & \text { plural } \\ \text { PTCP } & \text { participle } \\ \text { PRS } & \text { present } \\ \text { R } & \text { reflexive } \\ \text { S } & \text { subjective } \\ \text { SG } & \text { singular } \\ \text { VBLZ } & \text { verbalizer }\end{array}$

\section{References}

Brykina, Maria, Gusev, Valentin, Szeverényi, Sándor, and Wagner-Nagy, Beáta. 2016. Nganasan Spoken Language Corpus (NSLC): Archived in Hamburger Zentrum für Sprachkorpora. Version 0.1. Publication date December 23, 2016. http://hdl.handle.net/11022/0000-0001-B36C-C

Fejes, László 2018a. Utilization of Nganasan digital resources: a statistical approach to vowel harmony. In: Pirinen, Tommi A., Rießler, Michael, Rueter, Jack, Trosterud, Trond, and Tyers, Francis M., eds. Proceedings of the 4th International Workshop for Computational Linguistics for Uralic Languages (IWCLUL 2018). Helsinki: Association for Computational Linguistics, 121140.

Fejes, László 2018b. A rejtőzködő harmónia [Harmony in hiding]. Általános Nyelvészeti Tanulmányok 30: 37-70.

Fejes, László 2019. Mennyire új a nganaszan palatoveláris harmónia? [How new is the Nganasan palato-velar harmony?] In: Forgács, Tamás, Németh, Miklós, and Sinkovics, Balázs (eds.) A nyelvtörténeti kutatások újabb eredményei. 10. kötet [Recent findings in historical linguistics, vol. 10]. Szeged: Szegedi Tudományegyetem Magyar Nyelvészeti Tanszék, 105-117.

Hajdú, Péter 1962. Die Frage des Stufenwechsels in den samojedischen Sprachen. Ural-altaische Jahrbücher, 34: 41-54.

Hajdú Péter 1964. Morás nyelv-e a nganaszan? [Is Nganasan a moraic language?] Nyelvtudományi Közlemények, 66: 397-400.

Hakulinen, Lauri 1941. Suomen kielen rakenne ja kehitys. Ensimmäinen osa. Ääneja muoto-oppia. [The structure and development of the Finnish language. Vol. 1]. Helsinki: Otava. 
Helimski 1993 = Хелимский, Евгений 1993. Прасамодийские ә и ӛ: прауральские источники и нганасанские рефлексы. [The Proto-Samoyed ə and ə̈: their Proto-Uralic sources and Nganasan reflexes]: In: Sz. Bakró-Nagy, Marianne and Szíj, Enikő (eds.): Hajdú Péter 70 éves [Festschrift for Péter Hajdú, 70]. Budapest: MTA Nyelvtudományi Intézet, 125-133.

Helimski, Eugene 1998. Nganasan. In: Daniel Abondolo (ed.): The Uralic languages. London - New York: Routledge, 480-515.

ISKo: Hakulinen, Auli, Vilkuna, Maria, Korhonen, Riitta, Koivisto, Vesa, Heinonen, Tarja Riitta and Alho, Irja 2004. Iso suomen kielioppi [A big Finnish grammar]. Suomalaisen Kirjallisuuden Seuran Toimituksia 950. Hämeenlinna: Suomalaisen Kirjallisuuden Seura.

Kosterkina et al. 2001 = Костеркина, Н. Т., Момде, А. Ч. and Жданова, Т. Ю. Словарь нганасанско-русский и русско-нганасанский [Nganasan-Russian and Russian-Nganasan dictionary]. Санкт-Петерсбург: Филиал издательства «Просвещение».

Katzschmann, Michael 2008. Chrestomathia Nganasanica. Texte - Übersetzung Glossar - Grammatik. Bearbeitung der Нганасанская фольклорная хрестоматия zиsammengestellt von Kazis I. Labanauskas unter Berücksichtigung des Словарь нганасанско-русский и руссконганасанский. Norderstedt: Books on Demand.

Ladefoged, Peter and Maddieson, Ian (1996). The sounds of the world's languages. Oxford: Blackwell.

Maddieson, Ian (1984). Patterns of sounds. Cambridge: Cambridge University Press. Mikola, Tibor 1970: Adalékok a nganaszan nyelv ismeretéhez [Additional information on Nganasan]. Nyelvtudomány Közlemények, 72: 59-92.

Tereščenko 1979 = Терещенко, Н. М. Нганасанский язык [Nganasan language]. Ленинград: Наука.

Várnai, Zsuzsa 2002. Hangtan. In: Wagner-Nagy, Beáta (ed.) Chrestomathia Nganasanica. Szeged - Budapest: SZTE Finnugor Tanszék - MTA Nyelvtudományi Intézet.

Várnai, Zsuzsa 2005. Some problems of Nganasan phonology: Mora or syllable? In: Wagner-Nagy, Beáta (ed.). Mikola-konferencia 2004 [A Mikola conference]. Budapest-Szeged: Finnugor Tanszék, 113-126.

Várnai, Zsuzsa 2010. Quasi-consonantal stems in Nganasan: A possible analysis. Finnisch-Ugrische Mitteilungen, 32/33: 607-619.

Vaysman, Olga 2009. Segmental alternations and metrical theory. Cambridge, MA: MIT $\mathrm{PhD}$ dissertation.

Wagner-Nagy, Beáta 2018. A grammar of Nganasan. Leiden - Boston: Brill 